\begin{tabular}{|l|l|l||}
\hline \multicolumn{2}{|c|}{ PublisherInfo } \\
\hline \hline PublisherName & $:$ & Palgrave Macmillan UK \\
\hline \hline PublisherLocation & $:$ & London \\
\hline \hline PublisherImprintName & $:$ & Palgrave Macmillan \\
\hline \hline
\end{tabular}

\title{
Labour disputes in 2006
}

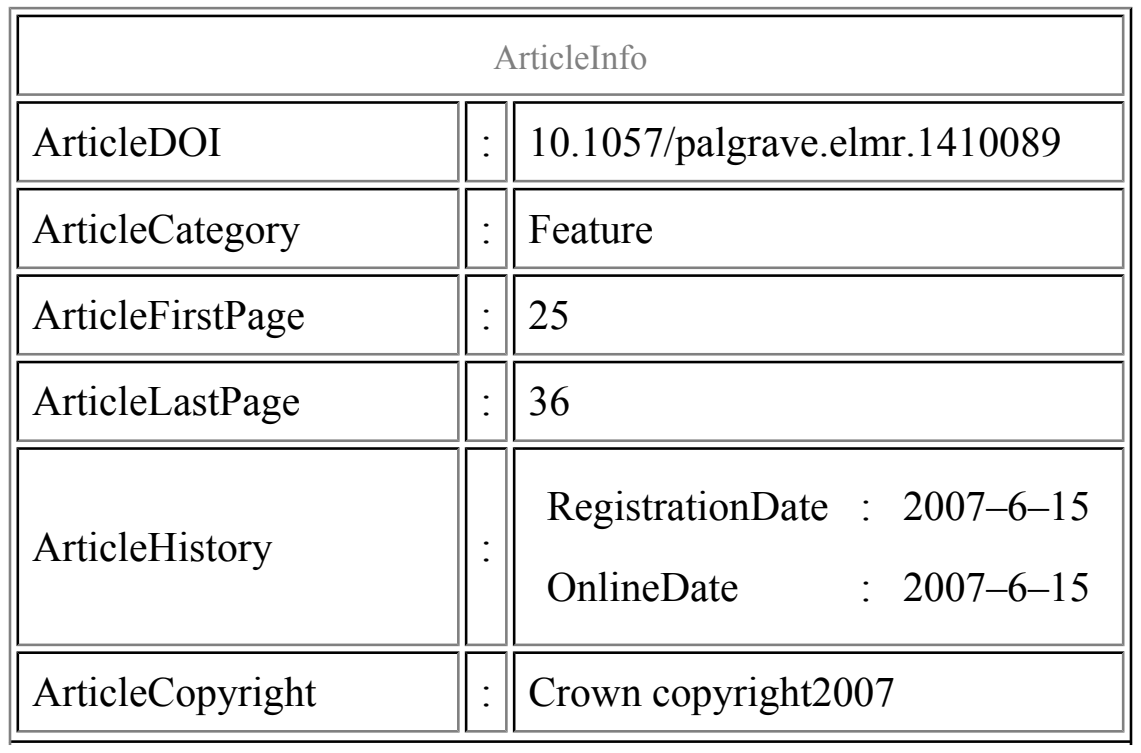




\section{Analyses the three main measures of labour disputes and puts the statistics into context in two separate ways.}

In 2006, 754,500 working days were lost in the UK from 158 stoppages of work arising from labour disputes.

This article analyses the three main measures of labour disputes - working days lost, stoppages and workers involved - by industry, region, cause, size and duration. The statistics are put into contextby considering estimates of working days lost per 1,000 employees and working time lost through strikes as a proportion of time actually worked.

Data are taken from a number of sources, including regular centralised returns from some industries and public bodies, as well as directly from the employer or trade union involved after the Office for National Statistics has been notified of a dispute from press reports.

The Full Text of this article can be found on the National Statistics website (http://www.statistics.gov.uk/elmr/06_07/downloads/ELMR06_07Hale.pdf). 